\title{
TRACE ELEMENTS IN MEDITERRANEAN MUSSELS Mytilus galloprovincialis FROM THE SOUTH AFRICAN WEST COAST
}

\author{
PIERWIASTKI ŚLADOWE W ŚRÓDZIEMNOMORSKICH MAŁŻACH Mytilus \\ galloprovincialis Z POŁUDNIOWEGO WYBRZEŻA AFRYKI ZACHODNIEJ
}

\begin{abstract}
Invasive bivalve molluscs, Mediterranean mussels (Mytilus galloprovincialis) were used as sentinel biomonitors of pollution by inorganic contaminants in Saldanha Bay and the Langebaan Lagoon area of South Africa. Two complementary analytical techniques, ICP-MS and NAA, allowed for determination of concentrations of 31 major and trace elements including heavy metals and arsenic in the soft tissues of the mussels. Distinct seasonal patterns were found in the dynamics of these concentrations, with the mussels accumulating much more trace elements in winter than in the summer. In general, the mussels that grew naturally also demonstrated higher concentrations of $\mathrm{As}, \mathrm{Cd}, \mathrm{Fe}, \mathrm{Hg}$ and $\mathrm{Zn}$ than those that were farmed. Fe showed the highest levels with a maximum concentration of $444 \mathrm{mg} / \mathrm{kg}$ followed by $\mathrm{Zn}$ with a maximum of $228 \mathrm{mg} / \mathrm{kg}$. The concentrations of Mn and $\mathrm{Pb}$ were significantly higher in the Port of Saldanha close to the jetty where ores containing these metals are loaded in comparison with the other sampling sites. It was concluded that bivalve molluscs present themselves as effective biomonitors when assessing marine aquatic pollution by inorganic contaminants in the Saldanha Bay region.
\end{abstract}

Keywords: biomonitoring, Inductivity Coupled Plasma-Mass Spectrometry, heavy metals, trace elements, Neutron Activation Analyses, bivalve molluscs, Mytilus galloprovincialis, Saldanha Bay area

\section{Introduction}

Saldanha Bay on the West Coast of South Africa is a natural deep-water harbour that forms an integrated system with the ecologically sensitive Langebaan Lagoon and wetland. The larger bay area accommodates several industrial activities such as seafood processing plants, steel industries, oilrig repair operations and multifunctional loading jetties.

\footnotetext{
${ }^{1}$ School for Science and Technology, Faculty of Military Science, Stellenbosch University, South Africa, phone +27 2270231 39, fax +27 2270230 60, email: jab@ma2.sun.ac.za

${ }^{2}$ Department of Microbiology, Stellenbosch University, South Africa, phone +27 $21 \quad 8085856$, fax +27 2180858 46, email: abo@sun.ac.za

${ }^{3}$ Sector of Neutron Activation Analysis and Applied Research, Division of Nuclear Physics, Frank Laboratory of Neutron Physics, Joint Institute for Nuclear Research, str. Joliot Curie, 6, 141980, Dubna, Moscow Region, Russian Federation, phone +74 9621656 09; fax +74 9621650 85, email: zoyag2012 @ gmail.com

${ }^{4}$ I.D. Papanin Institute of the Biology of Inland Waters, Russian Academy of Sciences, 152742, Borok, Yaroslavl' Region, Russian Federation, phone/fax +7(48547)24042, email: dpavlov.sr@gmail.com

*Corresponding author: marina@nf.jinr.ru
} 
The Saldanha Bay system is further acknowledged as an area having vital environmental value, and this was also emphasized by research and planning that was done into a new Industrial Development Zone (IDZ) at Saldanha Bay [1]. The IDZ has subsequently commenced under condition that environmental impacts would be taken into consideration and managed appropriately.

Langebaan Lagoon is an internationally recognised conservation area and a designated Ramsar Convention site. There are various concerns on the deterioration of water quality and ecological functioning of the lagoon due to the large industrial and urban impacts on the Saldanha Bay and Langebaan Lagoon system. This is evident from the ongoing environmental research by the Saldanha Bay Water Quality Trust (SBWQT). Their latest "State of the Bay" report shows that the situation has currently stabilised in some areas of the system but that the general trend in water quality tends to be negative [2]. This is a result of increasing anthropogenic activities in the region of the bay that subsequently causes various pollutants to enter the Saldanha Bay and Langebaan Lagoon system.

Environmental monitoring is essential to identify and minimise negative human impact on the environment. Monitoring is therefore particularly important for the Saldanha Bay and Langebaan Lagoon system, which has seen significant development in the last two decades. In 1975, Edward Goldberg [3] proposed to use bivalve molluscs as sentinel organisms for monitoring levels of environmental pollutants in water [1]. Since then the approach called "Mussel Watch" has been widely and successfully used in many countries worldwide, which includes the Cape Peninsula in South Africa [4, 5]. Bivalves are unique biomonitors as they are sedentary and actively filter large quantities of water per body weight. Water-born pollutants consequently tend to remain in their bodies and therefore bivalves provide a suitable long-term monitoring tool.

The Mediterranean mussels (Mytilus galloprovincialis) that are found in and around Saldanha Bay are the most abundant of all bivalve molluscs at South African coastal waters and were consequently chosen as biomonitors [6]. These invasive mussels were preferred owing to their much higher abundance compared to the indigenous black mussels (Choromytilus meridionalis) [7]. The Mediterranean mussels grow naturally on almost all the rocks in this part of the South African coastline, but are also farmed on rafts in the inner part of Saldanha Bay.

Mussels were sampled at different consequent locations in and around the bay. The samples were analysed by two complementary analytical techniques [8] - Inductivity Coupled Plasma-Mass Spectrometry (ICP-MS) and Neutron Activation Analysis (NAA). A comparison was made between elemental composition of samples collected at different sampling sites as well as the temporal (seasonal) variation of elemental concentrations at each site. The study was focused on arsenic and such heavy metals as cadmium, cobalt, copper, iron, lead, manganese, mercury, and zinc.

\section{Material and methods}

\section{Sampling}

Mussels were sampled at four sites that were spread over Saldanha Bay, Danger Bay and Langebaan Lagoon (see Fig. 1). The most natural and pristine sample site was in Danger Bay due to the fact that the bay is exposed to the open ocean as well as situated in a nature reserve relatively remote from any point sources of anthropogenic impact. Mussels were also sampled from a floating jetty at the Langebaan Yacht Club, which, 
in turn, is located in Langebaan Lagoon. Sampling point 1 in Saldanha Bay is very close to the multipurpose loading facility of the port and consequently is exposed to possible spillages from the jetty. Sampling point 2 in Saldanha Bay is close to the mouth of a perennial spring which is also used to discharge waste water from the town of Saldanha. The samples at two points in Saldanha Bay where collected from rafts of mariculture farms, ie these samples represent farmed mussels while the former two ones are naturally grown molluscs.

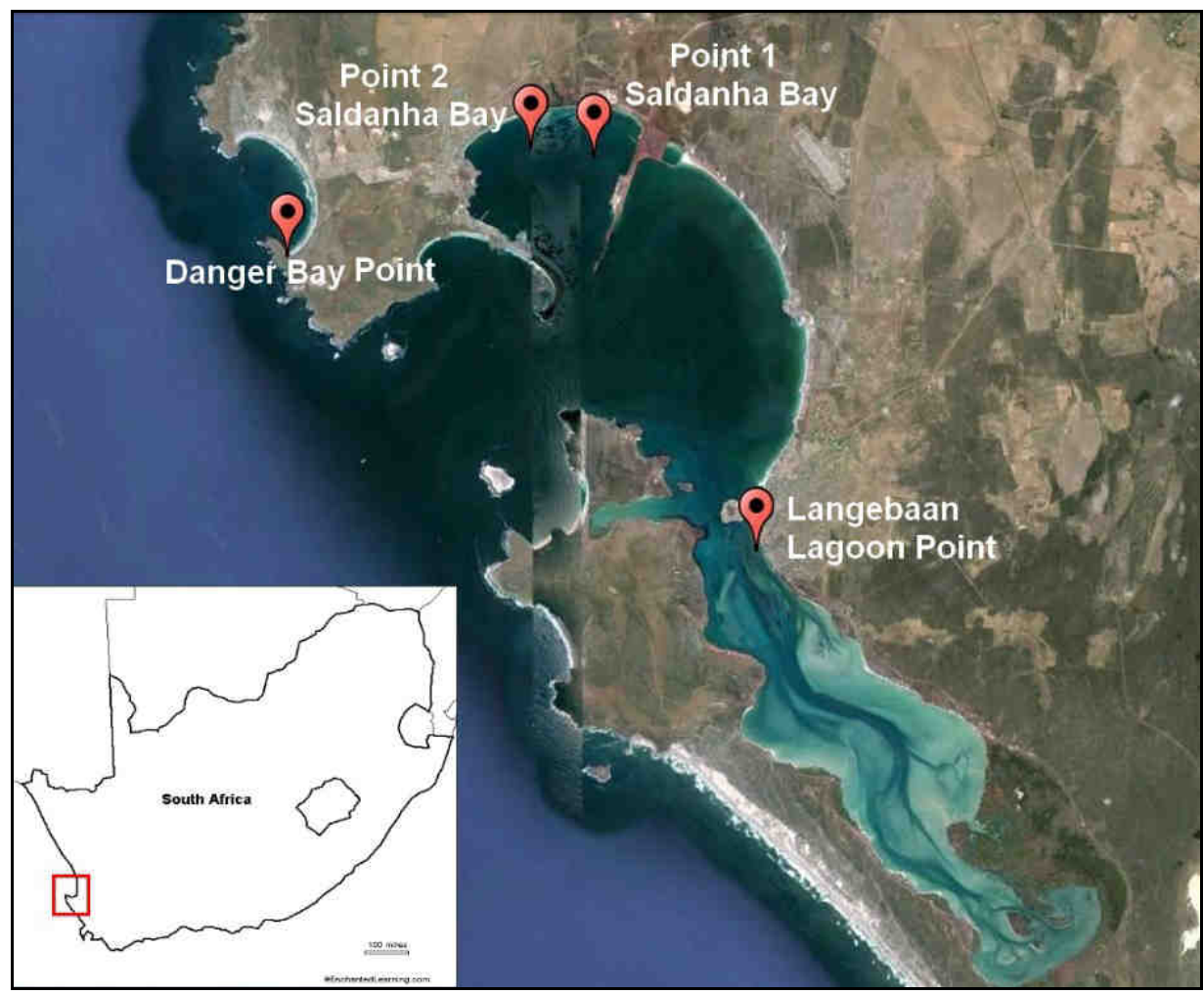

Fig. 1. A Google Earth image indicating the positions of the four sampling sites. The map insert shows the position of Saldanha Bay with relation to South Africa

Ten specimens of Mytilus galloprovincialis were sampled for each analysis from each of the four different sites. The samples were then packed and shipped to either the Stellenbosch University in South Africa or to the Joint Institute for Nuclear Research (JINR) in Dubna, Russia, for quantitative elemental analysis. The samples that were shipped to Russia were first washed in fresh water and then underwent some preliminary processing. The soft tissues and the shells of these samples were separated during this preliminary processing and then separately packed in plastic bags and frozen until shipped. Final processing and preparation of the mussels for ICP-MS and NAA were conducted at the respective institutes. 


\section{ICP-MS Analysis}

Samples that were sent for ICP-MS were collected every second month from March 2014 to March 2015 at each of the four sample sites. After each sampling, ICP-MS of a composite sample of the soft tissues of 10 mussels was conducted at a facility of the Stellenbosch University in South Africa. Approximately $0.5 \mathrm{~g}$ of wet weight of the composite sample was digested in a mixture of $8 \mathrm{~cm}^{3} \mathrm{HNO}_{3}$ and $2 \mathrm{~cm}^{3} \mathrm{HCl}$ (Merck, Suprapure) contained in a Teflon vessel. Digestion blanks and NIST Standard Reference Material (SRM) 1547 Peach Leaves were also prepared by the same procedure as the samples.

The ICP-MS measurements were carried out using an Agilent 7700x ICP-MS instrument. The operational parameters of the instrument were as follow: RF Power; $1600 \mathrm{~kW}$, carrier gas flow rate; $0.36 \mathrm{dm}^{3} / \mathrm{min}$, dilution gas; $0.63 \mathrm{dm}^{3} / \mathrm{min}$, spray chamber temperature; $2^{\circ} \mathrm{C}$ and a sensitivity; $90000 \mathrm{cps} / \mathrm{ppb}$ Y. To compensate for differences in the matrix between samples and standards, internal standards were introduced online. The following 16 elemental concentrations were determined by means of this process: $\mathrm{Al}$, As, $\mathrm{Ba}, \mathrm{Cd}, \mathrm{Co}, \mathrm{Cr}, \mathrm{Cu}, \mathrm{Fe}, \mathrm{Hg}, \mathrm{Mn}, \mathrm{Mo}, \mathrm{Ni}, \mathrm{Pb}, \mathrm{Se}, \mathrm{Sn}$, and $\mathrm{Zn}$. The results of the analyses are given in Figure 2 and the instrumental uncertainty is indicated with error bars.

\section{Neutron Activation Analysis}

Samples sent for NAA were collected every autumn (April) and spring (August) in 2012, 2013 and 2014 at Danger Bay, Saldanha Bay sampling point 1, and in March and August 2014 in Langebaan Lagoon. The NAA of the soft tissue of the mussels was performed at the reactor IBR-2 of Frank Laboratory of Neutron Physics, JINR, Dubna, Russia. The soft tissues were extracted from shells, and the samples were dried at a temperature of $40^{\circ} \mathrm{C}$ to a constant weight and homogenized with mortar and pestle. To determine short-lived isotopes $(\mathrm{Cl}, \mathrm{Mn}, \mathrm{V}, \mathrm{Mg}, \mathrm{Ca}$, and $\mathrm{I})$ approximately $0.3 \mathrm{~g}$ of material was packed in polyethylene bags, and then irradiated for 3-5 min in irradiation channel with the neutron flux density of $F_{e p i}=1.3 \cdot 10^{12} \mathrm{n} /\left(\mathrm{cm}^{2} \cdot \mathrm{s}\right)$. Gamma spectra of induced activity were measured using a HP Ge detector after 9-10 min of decay. To determine the long-lived isotopes ( $\mathrm{Na}, \mathrm{K}, \mathrm{As}, \mathrm{Br}, \mathrm{Sb}, \mathrm{Se}, \mathrm{Cr}, \mathrm{Fe}, \mathrm{Co}, \mathrm{Zn}, \mathrm{Rb}, \mathrm{Sr}, \mathrm{Mo}, \mathrm{Ag}, \mathrm{Ba}, \mathrm{Cs}$, Th, U), the samples were packed in aluminium cups and irradiated for 3 days in cadmium screened irradiation channel with the neutron flux density of $F_{e p i}=3.6 \cdot 10^{11} \mathrm{n} /\left(\mathrm{cm}^{2} \cdot \mathrm{s}\right)$. Gamma-ray spectra were measured after 3 and 20 days following the long irradiation. Quality control was provided by using NIST SRMs: 1547 Peach Leaves, 566b Oyster tissues, 1633b Coal fly ash, 2710 Montana soil and Certified Reference Material IAEA-433 Marine Sediment. The standards and reference materials were packed together with the samples in each transport container.

The results of ICP-MS are expressed as individual concentration values \pm analytical uncertainty. The results of NAA are presented with arithmetic means \pm standard deviation.

\section{Results and discussion}

The ICP-MS and NAA results are given in Figures 2 and 3, respectively. The ICP-MS results of $\mathrm{Zn}$ which was accumulated over a year show a distinct seasonal cycle (Fig. 2). The mussels tend to accumulate higher concentrations of $\mathrm{Zn}$ in the winter months from April to August than in summer. There were, however, no significant temporal trends in $\mathrm{Zn}$ concentrations and this was apparent from the NAA results that were obtained from 2012 to 
2014 (see Fig. 3). According to Eisler [10], molluscs preferentially accumulate Zn; and this may explain high concentrations of $\mathrm{Zn}$ in all marine organisms including mussels. However, the highest concentration of $\mathrm{Zn}$ in all the samples $(228 \mathrm{mg} / \mathrm{kg})$ was found to be below the maximum permissible level for food $(300 \mathrm{mg} / \mathrm{kg})$ as set by the South African Bureau of Standards (SABS) [11].

The dynamics of concentrations of all the elements and at all the sites that were analysed in the yearly cycle exhibited the trend similar to seasonal pattern of $\mathrm{Zn}$ content, ie these concentrations were elevated in winter compared to summer (see Fig. 2). The accumulation of elements by bivalve molluscs is not a passive process that solely depends on the elemental content of the water that molluscs filter. The rate of elemental accumulation can depend on a number of factors, eg on mollusc physiological state including a stage of reproductive cycle. We suggest that one of such factors responsible for the revealed seasonal dynamics of elemental concentrations may be spawning that takes place in summer, with a subsequent release of large mass of gametes [12] and, hence elimination of trace elements accumulated in gametes from molluscs' bodies.

The mussels sampled in Danger Bay and Langebaan Lagoon generally show higher concentrations of $\mathrm{Zn}$ than the farm grown mussels in Saldanha Bay. This trend is also visible in $\mathrm{Fe}, \mathrm{Cu}, \mathrm{Mn}, \mathrm{Hg}$ and As. According to both the ICP-MS and NAA results, As exhibited the most notable differences. These site-specific differences in the contents of determined elements in the tissues of the mussels can be explained by the differences in the environmental conditions at these sites as suggested by Pavlov et al [13]. The conditions in Danger Bay are more dynamic and challenging for the mussels as they inhabit rocks that are exposed to extreme weather conditions, opposed to the mussels in Saldanha Bay that are always submerged. This may result in more active metabolism in the natural mussels and hence in the more vigorous accumulation of elements. Another possible reason is the different composition of mussel food at the various sites, consequently resulting in different uptake of elements by the mussels. The mussels growing on the floating jetty at Langebaan Lagoon are exposed, for example, to large tide currents that flow in and out of the lagoon twice a day and the tide-driven waters may differ in the compositions of mussel food items. However, the above hypotheses need to be tested by further in-depth research.

Iron demonstrated the overall highest concentrations of all the elements that were measured in this study period. The highest value of $444 \mathrm{mg} / \mathrm{kg}$ was measured in Danger Bay in April 2013. The high Fe concentrations may be related to continental sources of Fe, as the major contributor to $\mathrm{Fe}$ is from rock weathering as a result of continental rainfall [14]. Saldanha Bay, however, houses a large steel industry and the Port of Saldanha loads huge amounts of iron ore yearly. During the 2013 and 2014 periods the port loaded on average 40 million metric tonnes of iron ore yearly [15]. Evidence of high levels of iron ore fallout is visible in a large area around the bay, and this consequently also impacts the water of the bay [16]. The levels of Fe that were measured in this study also exceeded those of other similar studies [2]. 


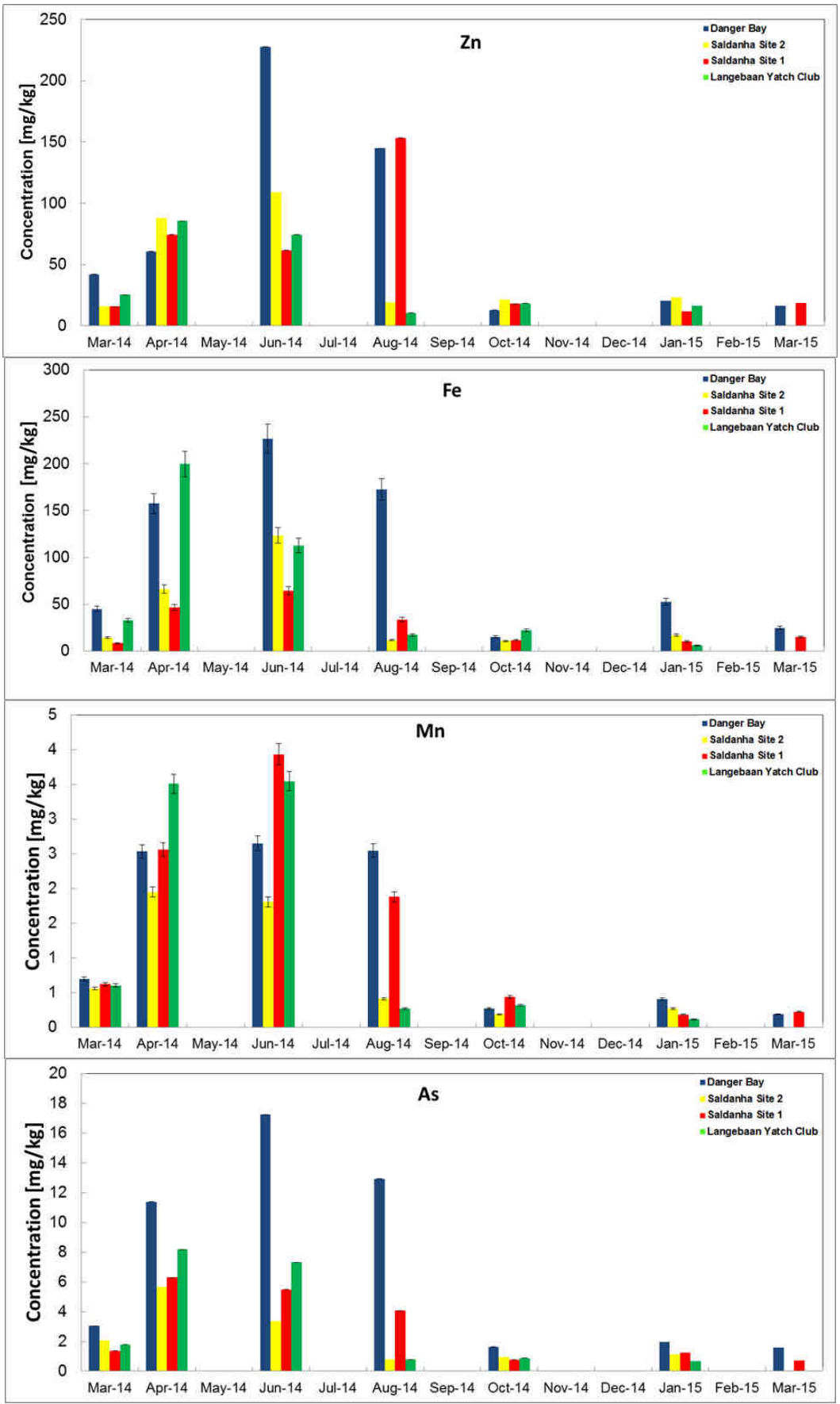



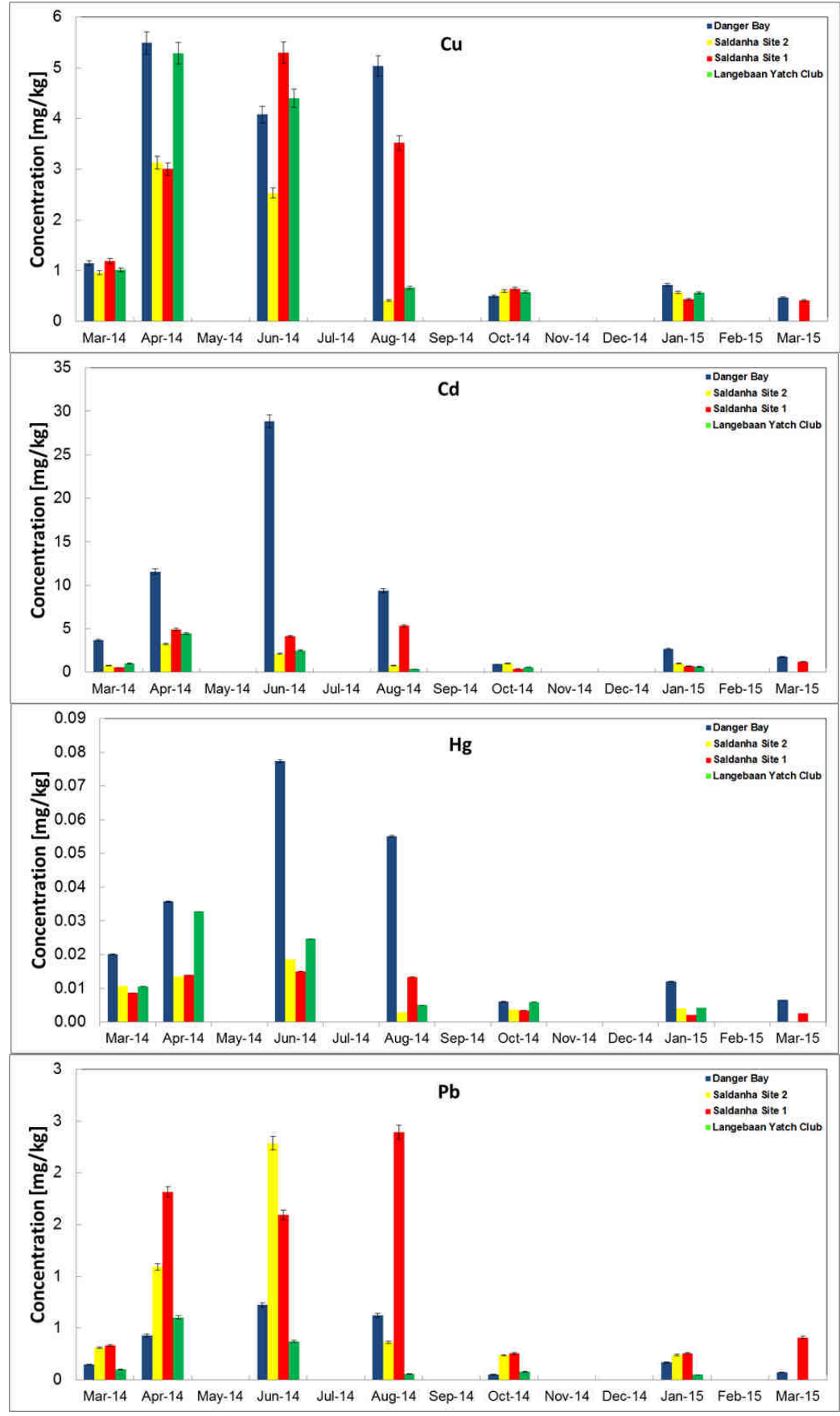

Fig. 2. Element concentrations ( $\mathrm{Zn}, \mathrm{Fe}, \mathrm{Mn}, \mathrm{As}, \mathrm{Cu}, \mathrm{Cd}, \mathrm{Hg}$ and $\mathrm{Pb}$ ) in soft tissue samples taken from March 2014 to March 2015, as determined using ICP-MS analysis. The four different samples sites are indicated in colour and the analytical uncertainties with error bars 
It is therefore reasonable to conclude that anthropogenic activities are responsible for Fe input into the Saldanha Bay and Langebaan Lagoon system, with subsequent high levels of $\mathrm{Fe}$ in the mussels of the area.

The study revealed that the concentrations of $\mathrm{Cd}$ and $\mathrm{Hg}$ (see Fig. 2) in the mussels of Danger Bay were notably higher than those in the other sampling points and the two elements demonstrated similar trends as well. Several studies have indicated that the level of water-borne $\mathrm{Cd}$ is rising all over the west coast of South Africa mainly due to urban discharge of water $[17,18]$. This spatially large-scale process may negatively affect even such generally pristine areas as Danger Bay. This is also evident in the Cd concentrations of the mussels of all four sites that exceed that regulatory limit of $3 \mathrm{mg} / \mathrm{kg}$ during the winter period. The $\mathrm{Hg}$ concentrations, however, only exceed the regulatory limit of $0.5 \mathrm{mg} / \mathrm{kg}$ in winter and only at the Danger Bay sampling site.

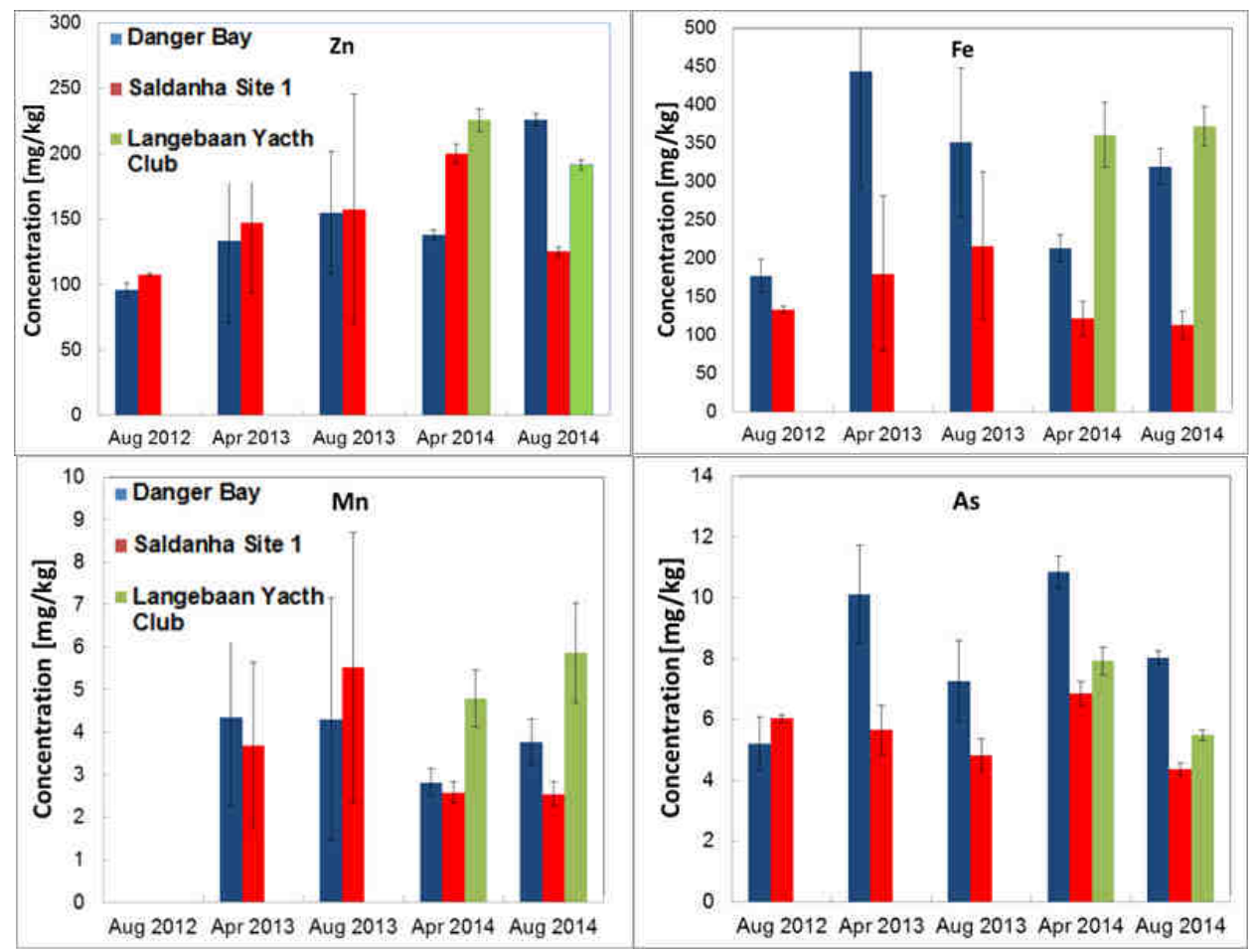

Fig. 3. Element concentrations in mussel flesh over the period August 2012 to August 2014 that were extracted by means of NAA techniques. The three different samples sites are indicated in colour and the error bars represent one standard deviation

The concentrations of $\mathrm{Mn}$ and $\mathrm{Pb}$ demonstrated high levels at the Saldanha Bay sampling points. The levels of $\mathrm{Pb}$ even exceeded the regulatory limit of $1.5 \mathrm{mg} / \mathrm{kg}$ during most of the winter of 2014. This can only be attributed to the loading of manganese and lead ores that takes place at the multipurpose loading facility of the port. This assumption is further supported by the "State of the Bay" report on the water quality of Saldanha Bay [2]. Mn did not show, however, an increase over the period starting from August 2012 to 
August 2014, as illustrated in Figure 3. The Saldanha Bay sampling point 1 that is closest to the multipurpose loading facility of the port shows significantly higher levels of $\mathrm{Mn}$ and $\mathrm{Pb}$, which further supports the contention that this may be due to spillages when loading the ores.

The Saldanha Bay sampling point 1 also demonstrates significantly high concentration of $\mathrm{Cu}$ during the winter months, which correlates with the elevated $\mathrm{Mn}$ and $\mathrm{Pb}$ concentrations. $\mathrm{Cu}$ is an important element in mussels as it is essential in the reproductive process, as well as forms a vital part of blood proteins $[19,20]$. The results therefore suggest that the mussels might have been under stress from their exposure to the high levels of $\mathrm{Mn}$ and $\mathrm{Pb}$ and were consequently adapting to that by accumulating more essential elements like $\mathrm{Cu}$. The levels of $\mathrm{Cu}$ were, however, still well below the maximum limits allowed in food as set by the SABS of $50 \mathrm{mg} / \mathrm{kg}$.

\section{Conclusion}

The concentrations of 31 major and trace elements including heavy metals and arsenic were measured in bivalve mollusc, Mediterranean mussels (Mytilus galloprovincialis), over different periods of time. The results obtained indicate that metal concentrations show notable temporal changes, and that the mussels accumulate much more trace elements in the winter than in the summer.

In general, the mussels that grew naturally demonstrated higher metal concentrations than those cultivated in mariculture farms in Saldanha Bay. However, the tissue levels of $\mathrm{Cu}, \mathrm{Mn}$ and $\mathrm{Pb}$ were elevated in the mussels farmed close to the multipurpose ores loading facility of the port where huge amounts of these metal ores are loaded. This gave reasonable indications of marine aquatic pollution due to spillages while loading takes place. Our present study confirms that the bivalve molluscs are good biomonitors to assess marine aquatic pollution, specifically when investigating trace elements. The Mussel Watch program in Saldanha Bay will continue and the results of our present study will serve a guideline for further sampling, as well as a baseline for the estimation of future trends.

\section{Acknowledgments}

The authors acknowledge the JINR-NRS grant for 2012-2015.

\section{References}

[1] Saldanha Bay IDZ Feasibility Study. Wesgro; 2011. http://wesgro.co.za/docs/SBIDZ_Feasibility_Study_ Report_Rev_1.pdf.

[2] State of Saldanha Bay and Langebaan Lagoon 2015 by the Saldanha Bay Water Quality Trust. Anchor Environment Consultant Report No. 1642/1. http://www.anchorenvironmental.co.za/Documents/Pdfs/.

[3] Goldberg E. The mussel watch - a first step in global marine monitoring. Marine Pollut Bull. 1975;6,7:111-123. DOI: 10.1016/0025-326X(75)90271-4.

[4] Farrington JW, Goldberg ED, Risebrough RW, Martin JH, Bowen VT. "Mussel Watch" 1976-1978: an overview of the trace-metal, DDE, PCB, hydrocarbon and artificial radionuclide data. Environ Sci Technol. 1983;17(8):490-496. DOI: 10.1021/es00114a010.

[5] Sparks C, Odendaal J, Snyman R. An analysis of historical Mussel Watch Programme data from the west coast of the Cape Peninsula, Cape Town. Marine Pollution Bulletin. 2014;87:374-380. DOI: 10.1016/j.marpolbul.2014.07.047.

[6] Robinson TB, Griffiths CL. Invasion of Langebaan Lagoon, South Africa, by Mytilus galloprovincialis effects on natural communities. African Zool. 2002;37(2):151-158. DOI: 10.2989/18142320509504088. http://planet.botany.uwc.ac.za/nisl/invasives/refs/robinson et al. 2005.pdf. 
[7] Hanekom N, Nel P. Invasion of Sandflats in Langebaan Lagoon, South Africa, by the alien mussel Mytilus galloprovincialis: Size, composition and decline of the populations. African Zool. 2002;37(2):197-208. http://reference.sabinet.co.za/document/EJC17835.

[8] Kawamoto K, Takada J, Tanaka Y, Akaboshi M. Determination of rare earth and other elements in standard samples by ICP-MS and activation analysis. J Radioanal Nucl Chem. 1999;242:527-530. DOI: 10.1007/BF02345586.

[9] Frontasyeva MV. Phys Particl Nuclei. 2011;42(2):332-378. DOI: 10.1134/S1063779611020043.

[10] Eisler R. Trace Metal Concentrations in Marine Organisms. New York: Pergamon Press; 1981. DOI: 10.4319/lo.1983.28.3.0600.

[11] Government Notice No. R. 1518 of 9 September 1994. South Africa; 1994. http://www.enviroleg.co.za/acts/Foodstuffs, Cosmetics and Disinfectants/REGS/.

[12] Van Erkom Schurink C, Griffiths CL. A comparison of reproductive cycles and reproductive output in four southern African mussel species. Marine Ecol Progr Serie. 1991;76:123-134. DOI: 10.3354/meps076123.

[13] Pavlov DF, Bezuidenhout J, Frontasyeva MV, Goryainova ZI. Differences in trace element content between non-indigenous farmed and invasive bivalve mollusks of the South African Coast. Amer J Analyt Chem. 2015;6:886-897. DOI: 10.4236/ajac.2015.611084.

[14] Giarratano E, Duarte CA, Amin OA. Biomarkers and metal bioaccumulation in mussels transplanted to coastal waters of the Beagle Channel. Ecotoxicol Environ Saf. 2010;73:270-279. DOI: 10.1016/j.ecoenv.2009.10.009.

[15] Kumba Iron Ore, Anglo American, official website (October 2015). http://www.angloamericankumba.com/ our-business/logistics.aspx.

[16] Iron Oxide Relationship to Staining Study, Transnet Port Terminals - Saldanha Port, Report by WSP Environmental;2015. https://www.wspgroup.com/Globaln/WSP_Africa/.

[17] Marine and coastal resources report of the South African Department of Environment. October 2015. https://www.environment.gov.za/sites/default/files/docs/part2_marineand_coastal_resources.pdf.

[18] Coastal Zone Report of the Western Cape Government. October 2015. https://www.westerncape.gov.za/ text/2005/12/06_soer_coastal_optimised.pdf.

[19] Cantillo AY. Comparison of results of Mussel Watch Programs of the United States and France with worldwide mussel watch studies. Marine Pollut Bull. 1998;36(9):712-717. DOI: 10.1016/S0025-326X(98)00049-6.

[20] Phillips DJH. The use of biological indicator organisms to monitor trace metal pollution in marine and estuarine environments - a review. Environ Pollut. 1977;13:281-317. DOI: 10.1016/0013-9327(77)90047-7.

\title{
PIERWIASTKI ŚLADOWE W ŚRÓDZIEMNOMORSKICH MAŁŻACH Mytilus galloprovincialis Z POŁUDNIOWEGO WYBRZEŻA AFRYKI ZACHODNIEJ
}

\begin{abstract}
Abstrakt: Inwazyjne małże śródziemnomorskie (Mytilus galloprovincialis) zostały wykorzystane jako biomonitor zanieczyszczenia związkami nieorganicznymi w Zatoce Saldanha i okolicy laguny Langebaan w Południowej Afryce. Dwie uzupełniające się techniki analityczne, ICP-MS i NAA, pozwoliły na określenie stężenia 31 głównych i śladowych pierwiastków, w tym metali ciężkich i arsenu w tkankach miękkich małży. Stwierdzono wyraźne sezonowe zmiany wartości stężeń analitów w małżach, które gromadzą o wiele więcej pierwiastków śladowych w zimie niż w lecie. Na ogół w małżach dzikich obserwowano większe stężenie As, Cd, Hg, Fe i Zn niż w hodowlanych. Wśród oznaczonych pierwiastków największe stężenie osiągnęło Fe, $\mathrm{z}$ maksymalnym stężeniem $444 \mathrm{mg} / \mathrm{kg}$, a następnie cynk z maksimum $228 \mathrm{mg} / \mathrm{kg}$. W porównaniu do innych miejsc pobierania próbek, stężenia Mn i Pb były istotnie większe w pobliżu molo w porcie Saldanha, gdzie są załadowywane rudy zawierające te metale. Stwierdzono, że małże są skutecznym biomonitorem zanieczyszczenia związkami nieorganicznymi morskiego środowiska wodnego w regionie Zatoki Saldanha.
\end{abstract}

Słowa kluczowe: biomonitoring, spektrometria mas sprzężona z plazmą wzbudzaną indukcyjnie, metale ciężkie, pierwiastki śladowe, neutronowa analiza aktywacyjna, małże, Mytilus galloprovincialis, region Zatoki Saldanha 